\title{
Are millennials moving to more urbanized and transit-oriented counties?
}

\author{
Devajyoti Deka \\ Rutgers, The State University of New Jersey \\ ddeka@ejb.rutgers.edu
}

\begin{abstract}
Recent studies show that two distinct narratives have emerged about the millennials' behavior, attitudes, and preferences regarding their choice of residence and transportation. According to the optimistic narrative, by living and traveling sustainably, millennials are planting the seeds of an urban renaissance. According to the pessimistic narrative, the changes in their behavior are due to economic constraints. To examine whether the inter-county migration pattern of American millennials is consistent with the optimistic narrative, this study compares some spatial and travel characteristics of the origins and destinations of millennials (age 25-34) and older adults (age 35-64) by using data from the 2011-2015 American Community Survey and the 2010 Longitudinal Employer-Household Dynamics. Basic comparisons show that the destinations chosen by millennials are likely to have the characteristics that are consistent with the optimistic narrative. The push-pull regression models show that the effects of the county characteristics on migration are often significant but modest. The effects are not remarkably different for the two age groups.
\end{abstract}

\section{Article history:}

Received: November 13, 2017

Received in revised form:

February 2, 2018

Accepted: March 25, 2018

Available online: July 2, 2018

\section{Introduction}

Millennials are broadly defined as persons born in the 1980s and 1990s. In a recent study, Delbosc and Ralph (2017) showed that two opposing narratives have emerged in the literature about the millennials, one an optimistic narrative that presumes the growth of millennials in cities and their disdain for the automobile as a generational paradigm shift potentially leading to an urban renaissance, and the other, a pessimistic narrative that attributes the seeming changes in the behavior and attitude of the millennials to adverse economic conditions created by the Great Recession. The divide between the optimistic and pessimistic views is also evident in a recent comprehensive review by RSG, Coogan, Rand Corp., Nelson Nygard, and Weinberger (2017), which additionally demonstrated that many uncertainties remain about the millennials' preference for urban/suburban living and their use of travel modes.

Copyright 2018 Devajyoti Deka

http://dx.doi.org/10.5198/jtlu.2018.1345

ISSN: 1938-7849 | Licensed under the Creative Commons Attribution - Noncommercial License 4.0

The Journal of Transport and Land Use is the official journal of the World Society for Transport and Land Use (WSTLUR) and is published and sponsored by the University of Minnesota Center for Transportation Studies. 
As explained in Section 2, the critical questions in the aforementioned debate revolve around the growth of millennials in cities and their preference for specific travel modes, especially mass transit and walking. To examine if working-age millennials are migrating to counties with a greater share of urban population, higher dwelling density, and a greater share of mass transit and walking trips, this study examines the county-to-county migration pattern of Americans aged 25-34 by using 2015 five-year summary (i.e., 2011-2015) data from the American Community Survey (ACS). It additionally analyzes the migration pattern of persons aged 35-64 so that a comparison can be made between the millennials and older adults in non-retiring age. The age group 25-34 was used as representative of millennials because other authors have also used that classification to study millennials (Moos, Pfeiffer, \& Vinodrai, 2018). By that definition, the oldest in the selected age group in 2011-2015 were born in 1977 and the youngest were born in 1990. Although persons aged 24 and younger in 2011-2015 would also qualify as millennials, they were not included in analysis because many of them could migrate for the purpose of attending educational institutions. Similarly, persons older than age 64 were not included in any analysis because retirees may have very different preferences compared to the working-age population. Because the comparison of the migration pattern of millennials with migration pattern of the older age group is conducted with cross-sectional data only to examine potential differences between the two groups at one time period, this comparison should not be viewed as an investigation into generational shift of migration patterns. The analysis pertaining to the older age group is conducted to inform how other people in working age are migrating.

Although the proponents of the optimistic narrative about millennials perceive cities and transit as attractors, this study merely examines whether the counties they are moving to are more urban, more dense, and more transit- and walk-oriented compared to the counties they are leaving behind. Because of the nature of the analysis conducted for the study, it cannot indicate whether millennials are attracted to cities and transit, but it can indicate whether the migration pattern of the millennials is consistent with the views of those who believe millennials are attracted to cities and transit. The study does not examine causal relationships between county characteristics and migration flows.

The primary method of analysis in this paper is the push-pull model, widely used in migration studies, but also used often in urban and regional planning. The models examine how spatial characteristics, especially the share of urbanized area population, density of dwelling units, and share of single detached homes, as well as the shares of mass transit, walking, and drive-alone trips for commuting, are associated with migration of the two aforementioned age groups. Most, but not all, model results are consistent with the claims of the proponents of the optimistic narrative that millennials are destined to urbanized areas and areas with greater share of transit and smaller share of driving trips, but the effects of urbanized area population, dwelling density, and travel modes are modest at best. The direction of the effects of the variables on migration of the two groups is mostly similar.

\section{Background}

A number of studies in recent times have suggested or provided impetus to the idea that beginning with the millennials, future generations of Americans will live predominantly in dense urban areas instead of low-density suburban areas that were preferred by the older generations (Center for Transit-Oriented Development, 2004; Gallagher, 2013; TransitCenter, 2014; Dutzik, Inglis, \& Baxandall, 2014; Talen, 2017). Such studies have also contributed to the view that future generations of Americans will prefer to use sustainable travel modes such as mass transit and walking instead of the automobile, which has been the preferred mode for most Americans for decades. According to Delbosc and Ralph (2017), this viewpoint provides optimism to planners who envision millennials as predominantly city dwellers who live and travel sustainably and prefer new communication technologies instead of the automobile. It 
appears from their review that studies adhering to this optimistic narrative far outnumber other studies that question this vision by attributing recent changes in behavior of the millennials to economic constraints. The authors attributed the findings in some optimistic studies to inappropriate data collection techniques, such as selective sampling of city dwellers.

The fruition of the optimistic narrative about sustainable millennials is not without basis. The number of young people in cities has increased in recent times more than the previous decades (Myers, 2016). They have also shown a greater desire to own homes in cities (Dickerson, 2016). Authors have claimed that the millennials not only prefer to live in cities, but they also have a distinct affinity for urbanism (Talen, 2017). A number of studies have found a decline in driving among young people (Polzin \& Chu, 2014). Studies have also shown that millennials have a lower propensity to acquire driver's licenses or they are acquiring licenses at an older age than the previous generation (Sivak \& Schoettle, 2012; RSG, Inc. et al., 2017). Studies have found an inverse relationship between intelligent communication technology use and driver's license acquisition (Sivak \& Schoettle, 2012). Large scale nationally conducted surveys have shown that young people are now embracing mass transit (TransitCenter, 2014). Similarly, a recent survey-based report from the Urban Land Institute (Kelly, Billingsley, Warren, \& Kramer, 2017) claims that the millennials prefer density, diversity, walkability, and transit.

Yet many have also shown skepticism about the changing behavior and attitude of the millennials regarding their affinity for cities and mass transit. Myers (2016) contended that the growth of millennials in cities is due to an increase in population in that age cohort instead of a special affinity for cities. Dickerson (2016) noted that the millennials are not buying homes in cities any more than previous generations despite their proclaimed affinity for cities. Kotkin and Cox (2013) argued that the growth of millennials is as common in low-density areas as it is in cities. Blumenberg, Ralph, Smart, and Taylor (2016) showed that the reduced driving of the millennials resulted from their lower employment rate instead of their lack of interest in driving. Klein and Smart (2017) showed that millennials are less likely to own cars because they have less money. Finally, the review of studies by RSG Inc. et al. (2017) showed that many contradictions exist between what the millennials seemingly want and what they choose, including housing location and travel mode. Because of these contradictions, the study's primary conclusion was that additional studies are needed to better understand the preferences and constraints of the millennials.

A reason for the evolution of the two distinct narratives about the millennials is that all millennials are not identical and they live in all types of places, including large cities, suburbs, small towns, and rural areas. As Moos, Pfeiffer, and Vinodrai (2018) explains, less-privileged millennials may live in basements of professional millennials. The focus of millennial studies has often been on professionals in selected affluent cities instead of poorer cities and regions. Furthermore, studies that have touched upon migration of millennials (e.g., Pfeiffer \& Pearthree, 2018; Mallach, 2018) have generally been conducted in the context of real estate market for specific cities. When studies are conducted predominantly in the context of specific cities, the millennials living in small towns and rural areas are ignored. To understand national trends, such populations are as important as the populations of large cities.

Despite identifying many studies exploring the preferences of millennials regarding travel modes and spatial characteristics, and other studies exploring millennials' choice of housing in specific cities, the literature search for this paper could not identify national studies that examined whether American millennials as a whole are migrating to urbanized areas, places with high population or housing density, or places where people have a higher propensity to travel more sustainably by walking or by taking mass transit. Benetsky and Fields (2015) studied migration patterns of millennials using ACS 3-Year estimates to examine the effect of the Great Recession on migration, but did not attempt to associate migration to spatial or travel characteristics of places. Piiparinen, Russell, and Post (2016) examined the migration 
destinations of millennials, but it was confined to only one city, Cleveland. Similarly, Jurjevich, Schrock, and Kang (2017) conducted a city-specific study for Portland, Oregon, but the study's objective was to examine demographic and socioeconomic characteristics of the migrants without any emphasis on travel modes or spatial characteristics of destinations. By examining the migration pattern of millennials as a whole for the country vis-à-vis some of the key spatial and travel characteristics of their places of origin and destination, this study bridges a gap in the literature. As the ACS provides nationally representative data from all types of areas, the results are devoid of data problems identified by Delbosc and Ralph (2017), such as selective sampling of places.

Because this study is about migration patterns, a brief overview of migration from a demographic perspective is pertinent. Although it has been more than 130 years since Ravenstein (1885) put forward his laws of migration and it has been more than 50 years since scholars such as Lee (1966) began to put forward theories of migration, more recent studies (e.g., Greenwood, 1997) show that migration is still an evolving field of study where generalization remains difficult. From Ravenstein (1885), Lee (1966), Jennissen (2007), and Davis, Fisher, and Veracierto (2010), it is evident that diversity between places, diversity of people, travel obstacles (i.e., distance), economic considerations, and social connections are some of the key considerations in migration studies, but how these factors affect each potential migrant is difficult to predict.

In the sphere of urban and regional economics, differences in housing cost, wages, and employment are highly emphasized as determinants of migration (Chen \& Rosenthal, 2008; Davis, Fisher, \& Veracierto, 2010). However, Korpi and Clark (2015) noted that primarily the highly educated workers migrate for employment and the share of those who migrate for employment purposes in the US is less than one third of all migrants. Noting that a quarter of the movers and more than $40 \%$ of the return movers move because of family reasons, Greenwood (1997) argued that a large number of people migrate for life events such as marriage, divorce, birth and aging of children, completion of schooling, retirement, etc., but because of the unavailability of data on such events, studies often ignore the effects of such events on migration. These studies show that migration is difficult to predict because it can be motivated not only by employment opportunities, but also by lifecycle needs. Predicting migration destination is also difficult because the advantages a place enjoys (e.g., jobs, income, or housing price) at a point in time may not last for long (Greenwood, 1997).

Despite the difficulties in generalizing the motivators of migration, a few facts are evident from empirical studies on internal migration in the US. First, the volume of migration has been decreasing in recent decades, prompting scholars to suggest that the causes may be aging of the population, decreasing differences between regions, increase in dual-income households, and decrease in marriage rates (Greenwood, 1997; Kaplan \& Schulhofer-Wohl, 2015; Cooke, 2018). Second, although migration from urban to suburban and exurban areas has often been highlighted in the US urban and regional planning context, migration from rural to urban areas has received little emphasis. In reality, migration from nonmetropolitan to metropolitan areas has continued to be a major force in population redistribution within the country. While Brown, Johnson, Loveland, \& Theobald (2005) noted the trend for the second half of the 20th century, more recent studies also show continued outmigration from rural to urban areas. Noting that as many as 1,351 nonmetropolitan counties lost population between 2010 and 2016, the US Department of Agriculture (2017) attributed the loss of rural population to persistent outmigration of young adults to urban areas. Brown et al. (2005) attributed the loss of rural population to mechanization of agriculture and rural people's attraction to economic and social opportunities in urban areas. Third, despite the difficulties in generalizing the reasons for migration, empirical studies show that young people, highly-educated people, high-income people, and renters migrate more than others, whereas married people and people with children migrate less (Greenwood, 1997; Molloy, Smith, \& Wozniak, 2011). 


\section{The push-pull model}

The primary method of analysis for this research is the push-pull model. The concept of push and pull factors in migration has been linked to Ravenstein (1885) by King (2012), who noted that the model is rooted in neo-classical economics. The basic concept of the model is that people migrate between places for their own benefit and therefore they leave behind places with unattractive attributes and move to places with attractive attributes. For example, from an economic perspective, places with low income, high unemployment, high housing cost, and poor educational system can be basic unattractive attributes and places with high income, low unemployment, low housing cost and good educational system can be attractive attributes.

The push-pull model has often been used to explain international migration, but has also been used to explain internal migration (e.g., Zimmermann, 1996; Schoorl, Heering, Esveldt, Groenewold, \& Van der Erf, 2000). A reason for the model's popularity is that it incorporates behavioral content into the basic gravity model (Greenwood, 1997). It is necessary for the model to include the sizes of the origins and destinations and the distance between the two, whereas the other variables in the model may vary. The sizes (i.e., population or geographic area) of the origins and destinations are included because larger places generate greater volumes of migrants, whereas distance (physical distance, cost, or time) is included because distance decreases the flow of migrants between places. The push-pull model includes additional variables pertaining to the origin, destination, or both. These variables are selected based on hypotheses of specific studies. Further details and mathematical formulations of the model can be found in Greenwood (1997).

Following Guest and Cluett (1976), who used a push-pull model to analyze workplace and residential location choice within the Los Angeles-Long Beach metropolitan area, Cervero (1989) used a model to examine the effects of job-housing imbalance in the San Francisco Bay area. The push-pull models in these studies were an extension of the gravity model, where the size (jobs and workers) of the origin and destination zones and distance separating the two were the primary control variables. The model used in this paper has the same basic structure, where population of the origin and destination counties and the distance separating the counties are the three most fundamental control variables. A few additional control variables pertaining to home value, income, jobs-labor force ratio, and education of the origin and destination counties have been included in the models with the hypothesis that economic considerations are more fundamental than the consideration of the hypothesized variables, namely, share of urbanized area population, density of dwellings, share of single detached homes, as well as the shares of transit, walking, and driving trips for commuting. The variables used in the models are described in Table 1. 
Table 1: Description of the variables

\begin{tabular}{|c|c|c|}
\hline Variables & Variable description & Nature of variable \\
\hline Migration flow & Natural log of county to county migration in one year & Dependent \\
\hline Origin population & Natural log of total population in origin county & Control \\
\hline Destination population & Natural log of total population in destination county & Control \\
\hline Distance between counties & Natural log of county to county distance (miles) & Control \\
\hline Origin building age & Natural log of median building age in origin county & Control \\
\hline Destination building age & $\begin{array}{l}\text { Natural log of median building age in destination } \\
\text { county }\end{array}$ & Control \\
\hline Origin income-home value ratio & $\begin{array}{l}\text { Ratio of median household income to median home } \\
\text { value in origin county }\end{array}$ & Control \\
\hline Destination income-home value ratio & $\begin{array}{l}\text { Ratio of median household income to median home } \\
\text { value in destination county }\end{array}$ & Control \\
\hline Origin low education & $\begin{array}{l}\text { Share of population age } 25 \text { and over with less than } \\
\text { high school diploma in origin county }\end{array}$ & Control \\
\hline Destination high education & $\begin{array}{l}\text { Share of population age } 25 \text { and over with bachelor's } \\
\text { degree or higher education in destination county }\end{array}$ & Control \\
\hline Origin jobs-labor force ratio & Jobs to labor force ratio in the origin county & Control \\
\hline Destination jobs-labor force ratio & Jobs to labor force ratio in the destination county & Control \\
\hline Origin urbanized area share & $\begin{array}{l}\text { Share of population in urbanized area (area with } \\
50,000+\text { population) in origin county }\end{array}$ & Hypothesized \\
\hline Destination urbanized area share & $\begin{array}{l}\text { Share of population in urbanized area (area with } \\
50,000+\text { population) in destination county }\end{array}$ & Hypothesized \\
\hline Origin dwelling density & Dwelling unit density per land acre in origin county & Hypothesized \\
\hline Destination dwelling density & $\begin{array}{l}\text { Dwelling unit density per land acre in destination } \\
\text { county }\end{array}$ & Hypothesized \\
\hline Origin single detached home share & Share of single detached homes in origin county & Hypothesized \\
\hline $\begin{array}{l}\text { Destination single detached home } \\
\text { share }\end{array}$ & Share of single detached homes in destination county & Hypothesized \\
\hline Origin transit share & $\begin{array}{l}\text { Share of commuting trips by transit in origin county } \\
\text { (excludes taxi) }\end{array}$ & Hypothesized \\
\hline Destination transit share & $\begin{array}{l}\text { Share of commuting trips by transit in destination } \\
\text { county (excludes taxi) }\end{array}$ & Hypothesized \\
\hline Origin walk share & Share of commuting trips by walking in origin county & Hypothesized \\
\hline Destination walk share & $\begin{array}{l}\text { Share of commuting trips by walking in destination } \\
\text { county }\end{array}$ & Hypothesized \\
\hline Origin drive alone share & $\begin{array}{l}\text { Share of commuting trips by driving alone in origin } \\
\text { county }\end{array}$ & Hypothesized \\
\hline Destination drive alone share & $\begin{array}{l}\text { Share of commuting trips by driving alone in destina- } \\
\text { tion county }\end{array}$ & Hypothesized \\
\hline
\end{tabular}

It ought to be noted that a number of variables on share of jobs in different sectors were also included in preliminary models in addition to the variables shown in Table 1 . However, the inclusion of those variables did not improve the explanatory power of the models. Although some of those variables showed results consistent with expectation, others did not. Moreover, the inclusion of the variables that showed results consistent with expectation adversely affected the results on more fundamental variables such as education level and the ratio of home value and income of the origin and destination counties. 
For those reasons, the share of jobs in different sectors was not included in the final models.

The functional form of the models in this paper can be described as follows:

$$
\ln Y_{i j}=f\left(\ln P_{i}, \ln P_{j}, \ln D_{i j}, \mathbf{Z}_{\mathbf{i}}, \mathbf{Z}_{\mathbf{j}}, \mathbf{X}_{\mathbf{i}}, \mathbf{X}_{\mathbf{j}}\right)
$$

Where $Y_{i j}$ is the migration flow between origin county $i$ and destination county $j, P_{i}$ is the population of origin county, $P_{j}$ is the population of destination county, $D_{i j}$ is the great circle distance (miles) between the origin and destination counties, $\mathbf{Z}_{\mathbf{i}}$ and $\mathbf{Z}_{\mathbf{j}}$ are vectors of control variables pertaining to the origin and destination counties, and $\mathbf{X}_{\mathbf{i}}$ and $\mathbf{X}_{\mathbf{j}}$ are vectors of hypothesized variables pertaining to the origin and destination counties. Similar to the models in Guest and Cluett (1976) and Cervero (1989), solutions to the models were obtained through ordinary least squares regression. Because the $\mathrm{X}$ vector of variables are not log transformed for mostly being proportions, but $\mathrm{Y}$ is log transformed, $\mathrm{Y}$ is to be interpreted as follows:

$$
\% \Delta Y=100 .\left(e^{\beta}-1\right)
$$

Where $e$ is the base of natural logarithm and $\beta$ is the coefficient of the hypothesized variables. The hypothesis for the models is that after controlling for the components of the standard gravity model (i.e., $P_{i}, P_{j}$, and $D_{i j}$ ) and the other control variables pertaining to income, housing value, jobs, and education (i.e., $\mathbf{Z}_{\mathbf{i}}$ and $\mathbf{Z}_{\mathbf{j}}$ ), the hypothesized variables will have coefficients that are consistent with the optimistic narrative about the millennials, namely, they would be likely to migrate to counties that have a higher share of urbanized area population, higher dwelling density, lower share of single detached homes, greater share of transit commuting trips, greater share of commuting trips by walking, and a smaller share of drive-alone commuting trips. A comparison of the models for people aged 25-34 with the models for people aged 35-64 would indicate if the former group is affected more by the attributes that are presumed to be important by the proponents of the optimistic narrative.

\section{$4 \quad$ Data and analysis}

\subsection{Data}

The data on migration flows was downloaded from the US Census Bureau's County-to-County Migration Flows: 2011-2015 ACS (US Census Bureau, 2017a). The ACS migration flows pertain to a 12 -month period. The geographic area for the counties was downloaded from the Bureau's 2015 Gazetteer Files (US Census Bureau, 2017b). The 2011-2015 ACS data on population and housing characteristics of counties was downloaded from the Bureau's American FactFinder (US Census Bureau, 2017c). Because the 2011-2015 ACS does not include data on population by type of area (i.e., urbanized area, urbanized cluster, and rural area), that variable was downloaded from 2010 Census by using American FactFinder. Block level data from 2010 on jobs was downloaded from the Census Bureau's Longitudinal Employer-Household Dynamics (LEHD) website and aggregated to the level of counties (US Census Bureau, 2017d). The great-circle distances between counties were downloaded from the National Bureau of Economic Research (2017) website.

The migration flow data and the county-to-county distance files were first combined. Subsequently the data on area, population, job, and housing characteristics of the origin and destination zones were attached to the dataset. The dataset used for analysis includes only county pairs between which migration took place during a 12-month period. It does not include intra-county migration flows because the origin and destination characteristics are the same for intra-county migration. When migrants are restricted to age 25-34, the dataset includes 59,050 county pairs; when they are restricted to age 35-64, it includes 105,616 county pairs. Because of missing data on certain variables for some county pairs, all 
of the county pairs could not be included in the statistical models.

\subsection{Basic comparison of destination characteristics}

Prior to undertaking the modeling effort, the characteristics of the destinations for migrants aged 25-34 were compared with the characteristics of the destinations for migrants aged 35-64 with the hypothesis that migrants from the younger group would be more likely to choose counties with higher proportion of persons in urbanized areas, higher dwelling density, lower share of single detached homes, higher shares of transit and walking trips, and lower share of drive alone trips. The comparison between the two age groups was made by estimating the weighted means of the variables as follows:

$$
M_{a}=\frac{\sum \mathrm{x}_{\mathrm{j}} \mathrm{N}_{\mathrm{j}}}{\sum \mathrm{N}_{\mathrm{j}}}
$$

Where $M_{a}$ is the mean for age group $a, X$ is one of the hypothesized variables, $j$ is destination county, and $N$ is number of migrants in age group $a$ migrating to $j$. It was important to estimate the weighted means because many counties the two groups migrate to are the same but the number of migrants is different for each group. The estimated means for the two age groups are presented in Table 2.

Table 2: Weighted mean of variables in the destination county

\begin{tabular}{|l|c|c|}
\hline \multicolumn{1}{|c|}{ Destination characteristics } & Age 25-34 & Age 35-64 \\
\hline Urbanized area share & 0.723 & 0.688 \\
\hline Dwelling density & 1.965 & 1.344 \\
\hline Single detached home share & 0.609 & 0.634 \\
\hline Transit trip share & 0.063 & 0.047 \\
\hline Walking trip share & 0.031 & 0.026 \\
\hline Driving alone trip share & 0.753 & 0.772 \\
\hline
\end{tabular}

The estimated means in Table 2 are consistent with the optimistic narrative about sustainable millennials because compared to the counties the older age group migrates to, the younger age group migrates to counties that have a higher share of urbanized area population, higher housing density, smaller share of single detached homes, greater share of transit and walking trips for commuting, and smaller share of drive-alone trips for commuting. However, the analysis does not account for the fact that the younger group may also be migrating from places with similar characteristics. Thus a comparison between the origin and destination counties through push-pull models can shed more light about their migration pattern.

\subsection{Models and results}

Detailed results from four push-pull regression models are presented in Tables 3 and 4 . The first two models, shown in Table 3, examine the relationship between the share of urbanized area population in the origin and destination counties with migration flow. The other two models, shown in Table 4, examine the relationship between the share of commuting trips by public transit in the origin and destination counties with migration flow. The left side of the two tables shows the models for migration of persons aged 25-34 and the right side shows the models for migration of persons aged 35-64. Eight similar models, four for each of the two age groups, were used to examine the relationship of migration flow with (a) dwelling density, (b) share of single detached homes, (c) share of walking trips for commuting, 
and (d) share of drive-alone trips for commuting at the origin and destination counties. Although for space limitations detailed results from these models are not presented, the observed relationship between migration flow and the hypothesized variables are summarized in Table 5.

Table 3: Regression models examining the relationship of the share of urbanized area population with county to county migration for people aged $25-34$ and people aged 35- 64

\begin{tabular}{|c|c|c|c|c|c|c|c|c|c|c|}
\hline \multirow[b]{2}{*}{ Variables } & \multicolumn{5}{|c|}{ Model for age 25-34 } & \multicolumn{5}{|c|}{ Model for age 35-64 } \\
\hline & Mean & $\begin{array}{l}\text { Std. } \\
\text { Dev. }\end{array}$ & Coeff. & $\begin{array}{c}\text { Robust } \\
t\end{array}$ & VIF & Mean & $\begin{array}{l}\text { Std. } \\
\text { Dev. }\end{array}$ & Coeff. & $\begin{array}{c}\text { Robust } \\
t\end{array}$ & VIF \\
\hline Migration flow & 2.89 & 1.17 & NA & NA & NA & 2.57 & 1.09 & NA & NA & NA \\
\hline Intercept & NA & NA & $0.763^{* *}$ & 6.90 & NA & NA & NA & $1.033^{* *}$ & 13.35 & NA \\
\hline Origin population & 12.09 & 1.60 & $0.185^{* *}$ & 29.54 & 4.67 & 12.11 & 1.60 & $0.150^{* *}$ & 33.97 & 4.78 \\
\hline $\begin{array}{l}\text { Destination popula- } \\
\text { tion }\end{array}$ & 11.87 & 1.57 & $0.262^{* *}$ & 42.79 & 4.53 & 11.84 & 1.55 & $0.227^{* *}$ & 51.96 & 4.60 \\
\hline $\begin{array}{l}\text { Distance between } \\
\text { counties }\end{array}$ & 4.78 & 1.37 & $-0.348^{* *}$ & -69.57 & 1.70 & 4.63 & 1.35 & $-0.283^{* *}$ & -85.71 & 1.63 \\
\hline Origin building age & 3.62 & 0.30 & $-0.190^{* *}$ & -10.55 & 1.38 & 3.61 & 0.30 & $-0.124^{* *}$ & -10.04 & 1.40 \\
\hline $\begin{array}{l}\text { Destination building } \\
\text { age }\end{array}$ & 3.62 & 0.30 & $-0.326^{* *}$ & -17.36 & 1.50 & 3.60 & 0.30 & $-0.403^{* *}$ & -30.94 & 1.54 \\
\hline $\begin{array}{l}\text { Origin income-home } \\
\text { value ratio }\end{array}$ & 0.34 & 0.10 & $-0.361^{* *}$ & -5.90 & 1.77 & 0.34 & 0.10 & $-0.169^{* *}$ & -3.93 & 1.83 \\
\hline $\begin{array}{l}\text { Destination income- } \\
\text { home value ratio }\end{array}$ & 0.35 & 0.10 & 0.020 & 0.31 & 1.92 & 0.35 & 0.10 & -0.048 & -1.05 & 1.93 \\
\hline Origin low education & 0.13 & 0.06 & $0.569^{* *}$ & 6.23 & 1.20 & 0.13 & 0.05 & $0.984^{* *}$ & 15.24 & 1.19 \\
\hline $\begin{array}{l}\text { Destination high } \\
\text { education }\end{array}$ & 0.27 & 0.11 & 0.059 & 0.92 & 2.40 & 0.26 & 0.11 & $-0.296^{* *}$ & -6.45 & 2.36 \\
\hline $\begin{array}{l}\text { Origin jobs-labor } \\
\text { force ratio }\end{array}$ & 0.84 & 0.25 & $0.115^{* *}$ & 5.33 & 1.32 & 0.83 & 0.25 & $0.032^{*}$ & 2.18 & 1.32 \\
\hline $\begin{array}{l}\text { Destination jobs- } \\
\text { labor force ratio }\end{array}$ & 0.84 & 0.25 & $0.134^{* *}$ & 5.87 & 1.49 & 0.82 & 0.24 & $0.077^{* *}$ & 4.75 & 1.48 \\
\hline $\begin{array}{l}\text { Origin urbanized } \\
\text { area share }\end{array}$ & 0.56 & 0.42 & $0.074^{* *}$ & 3.35 & 4.17 & 0.57 & 0.42 & $0.096^{* *}$ & 6.17 & 4.21 \\
\hline $\begin{array}{l}\text { Destination urban- } \\
\text { ized area share }\end{array}$ & 0.52 & 0.42 & 0.180 & 7.99 & 4.44 & 0.51 & 0.42 & $0.245^{* *}$ & 15.49 & 4.45 \\
\hline $\mathrm{N}$ & & & 50922 & & & & & 92260 & & \\
\hline Adjusted R square & & & 0.234 & & & & & 0.221 & & \\
\hline $\mathrm{F}$ & & & 1196 & & & & & 2010 & & \\
\hline $\operatorname{Pr}>\mathrm{F}$ & & & $<0.0001$ & & & & & $<0.0001$ & & \\
\hline $\begin{array}{l}\text { ** Significant at } 1 \% \\
\text { * Significant at } 5 \% \\
\text { VIF: Variance Inflat }\end{array}$ & Facto & & & & & & & & & \\
\hline
\end{tabular}


Table 4: Regression models examining the relationship of the share of transit commuting trips with county to county migration for people aged 25-34 and people aged 35-64.

\begin{tabular}{|c|c|c|c|c|c|c|c|c|c|c|}
\hline \multirow[b]{2}{*}{ Variables } & \multicolumn{5}{|c|}{ Model for age 25-34 } & \multicolumn{5}{|c|}{ Model for age 35-64 } \\
\hline & Mean & $\begin{array}{l}\text { Std. } \\
\text { Dev. }\end{array}$ & Coeff. & $\begin{array}{c}\text { Robust } \\
t\end{array}$ & VIF & Mean & $\begin{array}{l}\text { Std. } \\
\text { Dev. }\end{array}$ & Coeff. & $\begin{array}{c}\text { Robust } \\
t\end{array}$ & VIF \\
\hline Migration flow & 2.92 & 1.18 & NA & NA & NA & 2.60 & 1.09 & NA & NA & NA \\
\hline Intercept & NA & NA & $0.394^{* *}$ & 4.06 & NA & NA & NA & $0.464^{* *}$ & 6.83 & NA \\
\hline Origin population & 12.20 & 1.59 & $0.205^{* *}$ & 52.29 & 1.92 & 12.22 & 1.59 & $0.177^{* *}$ & 65.25 & 1.92 \\
\hline $\begin{array}{l}\text { Destination popu- } \\
\text { lation }\end{array}$ & 11.10 & 1.57 & $0.292^{* *}$ & 72.95 & 2.08 & 11.96 & 1.55 & $0.271^{* *}$ & 95.01 & 2.11 \\
\hline $\begin{array}{l}\text { Distance between } \\
\text { counties }\end{array}$ & 4.85 & 1.38 & $-0.361^{* *}$ & -76.77 & 1.69 & 4.68 & 1.37 & $-0.296^{* *}$ & -95.62 & 1.61 \\
\hline $\begin{array}{l}\text { Origin building } \\
\text { age }\end{array}$ & 3.63 & 0.30 & $-0.172^{* *}$ & -9.55 & 1.58 & 3.62 & 0.30 & $-0.120^{* *}$ & -9.72 & 1.58 \\
\hline $\begin{array}{l}\text { Destination build- } \\
\text { ing age }\end{array}$ & 3.63 & 0.30 & $-0.381^{* *}$ & -19.78 & 1.81 & 3.61 & 0.30 & $-0.451^{* *}$ & -33.79 & 1.83 \\
\hline $\begin{array}{l}\text { Origin income- } \\
\text { home value ratio }\end{array}$ & 0.33 & 0.10 & $-0.502^{* *}$ & -7.93 & 2.15 & 0.34 & 0.10 & $-0.313^{* *}$ & -7.06 & 2.19 \\
\hline $\begin{array}{l}\text { Destination } \\
\text { income-home } \\
\text { value ratio }\end{array}$ & 0.35 & 0.10 & $0.194^{* *}$ & 2.96 & 2.24 & 0.35 & 0.10 & $0.104^{*}$ & 2.23 & 2.21 \\
\hline $\begin{array}{l}\text { Origin low educa- } \\
\text { tion }\end{array}$ & 0.13 & 0.05 & $0.568^{* *}$ & 6.67 & 1.18 & 0.13 & 0.05 & $0.896^{* *}$ & 14.81 & 1.17 \\
\hline $\begin{array}{l}\text { Destination high } \\
\text { education }\end{array}$ & 0.28 & 0.12 & $0.196^{* *}$ & 3.47 & 2.37 & 0.27 & 0.11 & -0.067 & -1.63 & 2.31 \\
\hline $\begin{array}{l}\text { Origin jobs-labor } \\
\text { force ratio }\end{array}$ & 0.85 & 0.25 & $0.133^{* *}$ & 6.91 & 1.28 & 0.84 & 0.25 & $0.047^{* *}$ & 3.49 & 1.28 \\
\hline $\begin{array}{l}\text { Destination jobs- } \\
\text { labor force ratio }\end{array}$ & 0.85 & 0.26 & $0.166^{* *}$ & 7.98 & 1.51 & 0.83 & 0.25 & $0.131^{* *}$ & 8.75 & 1.50 \\
\hline $\begin{array}{l}\text { Origin transit } \\
\text { share }\end{array}$ & 0.03 & 0.08 & $-0.159^{*}$ & -2.09 & 1.80 & 0.03 & 0.08 & $-0.220^{* *}$ & -4.09 & 1.78 \\
\hline $\begin{array}{l}\text { Destination transit } \\
\text { share }\end{array}$ & 0.03 & 0.07 & $0.427^{* *}$ & 5.10 & 1.81 & 0.03 & 0.06 & $0.302^{* *}$ & 4.81 & 1.71 \\
\hline $\mathrm{N}$ & & & 57832 & & & & & 103928 & & \\
\hline Adjusted R square & & & 0.237 & & & & & 0.222 & & \\
\hline $\mathrm{F}$ & & & 1380 & & & & & 2278 & & \\
\hline $\operatorname{Pr}>\mathrm{F}$ & & & $<0.0001$ & & & & & $<.0001$ & & \\
\hline $\begin{array}{l}\text { ** Significant at } 1 \% \\
\text { * Significant at } 5 \% \\
\text { VIF: Variance Inflat }\end{array}$ & Facto & & & & & & & & & \\
\hline
\end{tabular}

For the results to be consistent with the optimistic narrative about millennials, one would expect millennials to migrate to counties with greater share of urbanized area population, greater dwelling density, lower share of single detached homes, greater shares of transit and walking trips, and lower share of drive-alone trips. These variables are examined with separate models because the study's objective is to examine consistency of results across the variables rather than to examine which of these variables has the strongest relationship with migration flow. Because many of these variables (e.g., dwelling density 
and share of single detached homes; share of transit trips and share of drive alone trips) are also highly correlated, inclusion of two or more of these variables in the same model would cause a serious multicollinearity problem.

For each model in tables 3, 4, and 5, the means and standard deviations of the variables are presented first, followed by the coefficients ( $\beta$ ), robust $t$ values, and the variance inflation factors (VIF). Robust $t$ values are presented to ensure that the significance of the variables accounts for heteroscedasticity. VIF for the variables was obtained to ensure that the models are not substantially affected by multicollinearity. VIF is not a statistical test, but standard econometrics textbooks recommend values lower than 10 (Kennedy, 2001) or 5 (Studenmund, 2001).

Because the control variables are identical in all models, they are discussed only once. The reasons for their inclusion, their hypothesized relationship with migration flow, and the implications of their estimated coefficients are discussed in the following paragraphs.

Among the control variables, population of the origin and destination counties and distance between the counties comprise the three components commonly used by push-pull models. These are also the necessary components of the model because they control for variations in size of the origin and destination counties and distances between county pairs. Because counties with greater population size are likely to generate more migrants, population size of origins and destinations is expected to have a positive relationship with migration. Because distance decreases migration, distance between counties is expected to have a negative relationship with migration flow. The high statistical significance of the three variables with expected sign in all models for both age groups in Tables 3 and 4 is consistent with expectation.

Median building age in the origin and destination counties is included with the hypothesis that migration would be greater from counties with higher median building age (i.e., older places) to counties with lower median building age (i.e., newer places). In order for this hypothesis to be supported by data, it is not necessary for the coefficient for the origin county to have a positive sign and the coefficient for the destination county to have a negative sign. If both coefficients have identical signs, one would expect the coefficient of the destination to be larger in absolute value than the coefficient for the origin. Because both building age and migration flow are log-transformed, the two estimated coefficients indicate the percent change of the dependent variable for one percent change in the independent variable. For example, the coefficients for the model for persons aged 25-34 in Table 3 indicate that one percent increase in median building age at the origin reduces out-migration by $0.19 \%$, whereas one percent increase in median building age at the destination reduces in-migration by $0.33 \%$. The coefficients together indicate that less migration occurs between counties with older buildings than between counties with newer buildings, but building age at the destination has a greater deterring effect than the origin. Although the negative sign of the coefficient for destination is easy to understand, the negative sign for the origin is also understandable when one considers that people in older places are more settled than people in newer places.

Instead of using median home value and median household income as separate variables, a composite variable was created because of a high degree of correlation between the two variables. Income also showed a similarly high correlation with rent, leading to VIF estimates far exceeding recommended thresholds. As a result, rent was not included in the models. The variable included in the models is the ratio of median household income to median home value. The expectation is that a high income to home value ratio in the origin county would deter out-migration and a high ratio in the destination county would promote in-migration. The results for both age groups in Tables 3 and 4 are mostly consistent with this expectation.

With the expectation that people would be more likely to emigrate from counties with low edu- 
cation level to counties with high education level, two variables on education were considered: share of persons aged 25 and over with less than high school graduation and share similar persons with a bachelor's degree or higher level of education. Because of high correlation between the variables, share of persons with less than high school graduation was included for the origin and share of persons with bachelor's degree or higher was included for the destination instead of including the two variables for both origin and destination.

Consistent with expectation, all models in Tables 3 and 4 showed that out-migration is higher from counties with lower level of education, but higher level of education at the destination is not always associated with greater in-migration. For the age group 25-34, higher education at the destination is positively and significantly associated with in-migration in all models except the model on share of urbanized area population, but for the age group 35-64, the variable is sometimes negatively associated, meaning that older people are less interested in migrating to such counties.

Finally, with the expectation that people would be more likely to migrate to counties with more jobs relative to labor force, jobs to labor force ratio at the origin and destination were included in all models. The larger value of the variable for the destination counties relative to the origin counties in Tables 3 and 4 is consistent with the expectation because it shows that people are likely to migrate to areas with more jobs relative to labor force.

The results on the hypothesized variables from all 12 models (six for each age group), including the four shown in Tables 3 and 4, are presented in Table 5. Because the control variables showed similar results in all models, their results in the other six models are not presented to reduce redundant information.

The hypothesized variables in Table 5 are share of urbanized area population, density of dwelling units, share of single detached homes, share of transit trips for commuting, share of walk trips for commuting, and share of drive-alone trips for commuting. The table shows that share of urbanized area population at the origin and destination is significant and positive in the models for both age 25-34 and age 35-64. In both cases the coefficients are greater for the destination than the origin, indicating that the net effect of the share of urbanized area population is positive for both groups.

The table also shows that dwelling density at the origin is significant at the 5\% level for age 25-34 and significant at the $1 \%$ level for age 35-64, both with negative signs, whereas density at destination is significant and positive at the $1 \%$ level for both age groups. The results indicate that less outmigration takes place from counties with high density and more in-migration takes place to counties with high density. The table shows that share of single detached home at both origin and destination is negatively related to migration for persons aged 25-34, but the coefficient is larger in absolute value at the destination, meaning that its effect is larger at the destination than the origin. For persons aged 35-64, the variable is not significant at the origin, but significant with the expected negative sign at the destination. On the whole, the models show that share of single detached homes may have a negative effect on migration at both ends, but the effect is larger at the destination than the origin. The results are consistent with the previous results because the share of single detached homes should be inversely related to share of urbanized area population and dwelling density.

Table 5 also shows that for persons aged 25-34, the share of transit commuting trips at the origin is significant and negative, whereas it is significant and positive at the destination. The coefficients are thus consistent with the optimistic narrative about the millennials. For persons aged 35-64 also, transit share is significant at both origin and destination with similar signs, indicating that greater share of transit trips at the origin is associated with lower out-migration and greater share of transit trips at the destination is associated with greater in-migration. One cannot come to the same conclusion about the share of commuting trips by walking from the results because the coefficient of walk share is larger at the origin than destination for persons aged 25-34, whereas it is not significant at the origin and significant with a 
negative sign at the destination for persons aged 35-64. Overall the models do not indicate that share of walking trips for commuting is consistent with the optimistic narrative.

Table 5: Summary of model results on the hypothesized variables

\begin{tabular}{|c|c|c|c|c|c|c|c|c|c|c|}
\hline \multirow[b]{2}{*}{ Variables } & \multicolumn{5}{|c|}{ Model for age 25-34 } & \multicolumn{5}{|c|}{ Model for age 35-64 } \\
\hline & Mean & $\begin{array}{l}\text { Std. } \\
\text { Dev. }\end{array}$ & Coeff. & $\begin{array}{c}\text { Robust } \\
t\end{array}$ & VIF & Mean & $\begin{array}{l}\text { Std. } \\
\text { Dev. }\end{array}$ & Coeff. & $\begin{array}{c}\text { Ro- } \\
\text { bust t }\end{array}$ & VIF \\
\hline $\begin{array}{l}\text { Origin urbanized } \\
\text { area share }\end{array}$ & 0.56 & 0.42 & $0.074^{* *}$ & 3.35 & 4.17 & 0.57 & 0.42 & $0.096^{* *}$ & 6.17 & 4.21 \\
\hline $\begin{array}{l}\text { Destination urban- } \\
\text { ized area share }\end{array}$ & 0.52 & 0.42 & $0.180^{* *}$ & 7.99 & 4.44 & 0.51 & 0.42 & $0.245^{* *}$ & 15.49 & 4.45 \\
\hline $\begin{array}{l}\text { Origin dwelling } \\
\text { density }\end{array}$ & 0.90 & 3.89 & $-0.003^{*}$ & -2.16 & 1.38 & 0.88 & 3.85 & $-0.003^{* *}$ & -3.47 & 1.37 \\
\hline $\begin{array}{l}\text { Destination dwell- } \\
\text { ing density }\end{array}$ & 0.81 & 3.68 & $0.006^{* *}$ & 4.37 & 1.33 & 0.66 & 3.01 & $0.004^{* *}$ & 3.04 & 1.25 \\
\hline $\begin{array}{l}\text { Origin single de- } \\
\text { tached home share }\end{array}$ & 0.65 & 0.14 & $-0.201^{* *}$ & -4.23 & 2.25 & 0.66 & 0.13 & 0.038 & 1.11 & 2.31 \\
\hline $\begin{array}{l}\text { Destination single } \\
\text { detached home } \\
\text { share }\end{array}$ & 0.66 & 0.13 & $-0.431^{* *}$ & -9.47 & 2.06 & 0.67 & 0.13 & $-0.327^{* *}$ & -9.71 & 1.98 \\
\hline Origin transit share & 0.03 & 0.08 & $-0.159^{*}$ & -2.09 & 1.80 & 0.03 & 0.08 & $-0.220^{* *}$ & -4.09 & 1.78 \\
\hline $\begin{array}{l}\text { Destination transit } \\
\text { share }\end{array}$ & 0.03 & 0.07 & $0.427^{* *}$ & 5.10 & 1.81 & 0.03 & 0.06 & $0.302^{* *}$ & 4.81 & 1.71 \\
\hline Origin walk share & 0.03 & 0.02 & $1.760^{* *}$ & 7.41 & 1.64 & 0.03 & 0.02 & 0.175 & 1.01 & 1.649 \\
\hline $\begin{array}{l}\text { Destination walk } \\
\text { share }\end{array}$ & 0.03 & 0.02 & $1.349^{* *}$ & 5.89 & 1.69 & 0.03 & 0.02 & $-0.376^{*}$ & -2.10 & 1.626 \\
\hline $\begin{array}{l}\text { Origin drive alone } \\
\text { share }\end{array}$ & 0.78 & 0.10 & $-0.314^{* *}$ & -5.14 & 1.754 & 0.78 & 0.094 & -0.052 & -1.21 & 1.75 \\
\hline $\begin{array}{l}\text { Destination drive } \\
\text { alone share }\end{array}$ & 0.78 & 0.09 & $-0.581^{* *}$ & -9.33 & 1.701 & 0.79 & 0.081 & $-0.272^{* *}$ & -5.73 & 1.61 \\
\hline $\begin{array}{l}\text { ** Significant at } 1 \% \\
* \text { Significant at } 5 \% \\
\text { VIF: Variance Inflat }\end{array}$ & Facto & & & & & & & & & \\
\hline
\end{tabular}

The share of drive-alone trips for commuting is significant and negative at both ends for persons aged 25-34 and the coefficient is larger at the destination than the origin, indicating that its effect is larger at the destination. This result is consistent with the optimistic narrative about millennials because of their supposed aversion to the automobile. The variable is not significant for origin in the model for persons aged 35-64 but significant with a negative sign for the destination, showing that share of drivealone trips for commuting is inversely related to in-migration for this age group also.

By using Equation 2 with the with model results, one can estimate the effects of the hypothesized variables on the magnitude of migration. For example, all else being equal, if the share of urbanized area population at the destination for age group $25-34$ increases by $50 \%$ from mean $52 \%$ to $78 \%$, inmigration will increase by only about $5 \%$. Similarly, if the share of transit commuting trips increases 
by $50 \%$ from mean $3.2 \%$ to $4.8 \%$ at the destination, in-migration will increase by less than $1 \%$. They show that despite being statistically significant, the effects of the hypothesized variables on migration flow are very small. It can be shown from the model results that the effects of the control variables are significantly larger.

\subsection{Synthesis of the effect of changes in the variables on migration}

The model results in Table 5 are mostly consistent with the optimistic narrative in that they show millennials moving to counties with a greater share of urbanized area population, greater dwelling density, lower share of single detached homes, greater share of transit commuting trips, and lower share of drivealone commuting trips relative to their counties of origin. If these variables continue to have the same relationship with migration over time, there will be more millennials living in urbanized areas, places with higher dwelling density, and places with greater transit use, whereas fewer of them will live in counties with higher share of single detached homes and higher share of drive-alone commuting trips. A future with more people in urbanized and more densely populated areas with greater share of transit trips is possible not only because of the millennials' potential preference for such areas, but also because of external factors such as increasing size of metropolitan areas, increasingly density in urban areas, and outmigration of people from rural/semi-rural areas to urban/suburban areas.

The model results do not necessarily indicate that the aforementioned county characteristics affect the migration of people aged 25-34 very differently from the way they affect the migration of people aged 35-64. This has been explained with the help of Table 6, where the effects of the six hypothesized variables are summarized.

Table 6: Percent change of county to county migration flow from $10 \%$ increase of the hypothesized variables at the mean

\begin{tabular}{|l|r|r|r|r|r|r|}
\hline & \multicolumn{3}{|c|}{ Model for age 25-34 } & \multicolumn{3}{c|}{ Model for age 35-64 } \\
\hline \multicolumn{1}{|c|}{ Variables } & $\begin{array}{c}\text { Previous } \\
\text { County }\end{array}$ & $\begin{array}{c}\text { Current } \\
\text { County }\end{array}$ & Difference & $\begin{array}{c}\text { Previous } \\
\text { County }\end{array}$ & $\begin{array}{c}\text { Current } \\
\text { County }\end{array}$ & Difference \\
\hline Urbanized area share & $0.42 \%$ & $0.94 \%$ & $0.52 \%$ & $0.54 \%$ & $1.25 \%$ & $0.71 \%$ \\
\hline Dwelling density & $-0.03 \%$ & $0.05 \%$ & $0.08 \%$ & $-0.03 \%$ & $0.02 \%$ & $0.05 \%$ \\
\hline Single detached home share & $-1.30 \%$ & $-2.80 \%$ & $-1.50 \%$ & $\mathbf{0 . 2 5} \%$ & $-2.17 \%$ & $-2.42 \%$ \\
\hline Transit trip share & $-0.05 \%$ & $0.14 \%$ & $0.19 \%$ & $-0.07 \%$ & $0.08 \%$ & $0.16 \%$ \\
\hline Walking trip share & $0.50 \%$ & $0.39 \%$ & $-0.11 \%$ & $\mathbf{0 . 0 5} \%$ & $-0.10 \%$ & $-0.15 \%$ \\
\hline Driving alone trip share & $-2.42 \%$ & $-4.45 \%$ & $-2.02 \%$ & $-\mathbf{0 . 4 1 \%}$ & $-2.12 \%$ & $-1.71 \%$ \\
\hline Bold font indicates not significant at 5\% level & & & &
\end{tabular}

Table 6 shows the effect of $10 \%$ increase in the hypothesized variables on migration flow by using the model coefficients and means of both the hypothesized and control variables shown in Table 5. It is evident from the table that $10 \%$ increase in all six variables leads to only modest changes in migration, indicating that the effect of the variables on migration is small even when they are statistically significant. From the first row of the table, it is evident that $10 \%$ increase in the share of urbanized area population at the origin increases out-migration at the origin my $0.42 \%$, but it increases in-migration at the destination by $0.94 \%$, indicating a net increase of $0.52 \%$. The net difference for persons aged $35-64$ is higher at $0.71 \%$, indicating that the overall effect of the variable is greater for persons aged 35-64 than persons aged 25-34. The effect of dwelling density is much smaller for both age groups, but the net effect is slightly greater for the younger age group $(0.08 \%$ versus $0.05 \%)$. However, the net effect of share of single detached homes is greater for persons aged 35-64. The net effects of the variables on share of 
transit trips and share of drive-alone trips are only modestly different for the two age groups, but in both cases the effects are larger for the younger age group than the older age group. On the whole, it is difficult to conclude from the results in Table 6 that all hypothesized variables have a greater effect on the migration of persons aged 25-34 than the migration of persons aged 35-64. In sum, even though the variables have a modest effect on outmigration from counties with smaller share of urbanized area population, lower density, higher share of single detached homes, lower share of transit trips, and greater share of drive-alone trips to counties with larger share of urbanized area population, higher dwelling density, lower share of single detached homes, higher share of transit trips, and lower share of drive-alone trips, they seem to affect people in the two age groups similarly. Although the net effects are slightly different in magnitude, the direction of the effects is mostly similar.

\section{$5 \quad$ Conclusions}

By using data on county-to-county migration from the 2011-2015 ACS, this paper examined how some of the spatial and travel-related variables perceived to have an effect on the millennials are associated with the migration of persons in age groups 25-34 and 35-64. It was hypothesized that the results would be consistent with the optimistic narrative in the literature if the younger group showed stronger relationships with the hypothesized variables in the expected direction.

A comparison of weighted means of these variables for the destination counties showed that, compared to the older group, the younger group could be moving more to urbanized areas, areas with higher housing density, areas with smaller share of single detached homes, and areas with greater shares of transit and walking trips for commuting. However, the push-pull regression models showed that the net effects of these variables are not necessarily greater for the younger group than the older group. The models showed that the effects of the aforementioned variables on migration are often statistically significant but modest in magnitude. The models also showed that the effects vary from variable to variable, thus preventing any kind of generalization in favor of either age group.

Returning to the literature, the optimistic narrative defined by Delbosc and Ralph (2017) - millennials flocking to cities, giving up driving, and using mass transit-is not necessarily without basis because some of the results in this paper show people migrating to counties with more urban characteristics compared to the counties they left behind. However, the effect of these characteristics on their migration was found to be modest. Furthermore, most of the spatial and travel characteristics of counties that are positively associated with migration of young people also seem to be positively associated with migration of older adults. This finding is perhaps more desirable than finding only younger people being affected by the aforementioned characteristics, although it may not add to the excitement of planners and professionals eager to declare the millennials as vastly different for their seemingly sustainable behavior and attitude.

A few cautionary remarks are important at the end to ensure that the study's findings are properly interpreted. First, because the ACS provides migration flow data for only county pairs between which sufficiently large number of people migrate within a 12-month period, the results are more applicable to counties generating moderate to large volumes of migration. The results may not apply very well to individual county pairs if the flows between the counties are small. That is because the coefficients of variation of migration flow are usually larger for counties that generate small volumes of migration. Second, because regression models best describe relationships near the means of the variables, the results may not apply well for counties with extreme characteristics, such as extremely high or low dwelling density. Third, because data are not available for counties nationwide on travel mode use for non-work purposes, the travel mode variables used in this research pertain to commuting only. Although there may 
be variations among counties regarding the use of travel modes for non-work purposes, this research does not account for those variations. Finally, because the study is based on county-level data, it could not examine the effects of local area characteristics such as street design, walkability, land-use mix, etc. Studies for specific metropolitan areas would be beneficial to understand the effects of those variables on migration, although they would not be able to provide a perspective for the nation as a whole. 


\section{References}

Benetsky, M. J., \& Fields, A. (2015). Millennial migration: How has the Great Recession affected the migration of a cohort as it came of age? SEHSD working paper No. 2015-1. U.S. Washington, DC: US Census Bureau.

Blumenberg, E., Ralph, K., Smart, M., \& Taylor, B. D. (2016). Who knows about kids these days? Analyzing the determinants of youth and adult mobility in the US between 1990 and 2009. Transportation Research Part A: Policy and Practice, 93, 39-54.

Brown, D. G., Johnson, K. M., Loveland, T. R., \& Theobald, D. M. (2005). Rural land-use trends in the conterminous United States, 1950-2000. Ecological Applications, 15(6), 1851-1863.

Center for Transit Oriented Development. (2004). Hidden in plain sight: Capturing the demand for housing near stations. Oakland, CA: Reconnecting America. Retrieved from http://www.reconnectingamerica.org/assets/Uploads/2004Ctodreport.pdf

Cervero, R. (1989). Jobs-housing balancing and regional mobility. Journal of the American Planning Association, 55(2), 136-150.

Chen, Y., \& Rosenthal, S. S. (2008). Local amenities and life-cycle migration: Do people move for jobs or fun? Journal of Urban Economics, 64(3), 519-537.

Cooke, T. (2018). United States: Cohort effects on long-term decline in migration rates. In T. Champion, T. Cooke, \& I. Shuttleworth (Eds.), Internal migration in developed world (pp. 101-119). New York: Routledge.

Davis, M., Fisher, J., \& Veracierto, M. (2010). The role of housing in labor reallocation. Working Paper 2010-18. Chicago: Federal Reserve Bank of Chicago.

Delbosc, A., \& Ralph, K. (2017). A tale of two millennials. Journal of Transport and Land Use, 10(1), $57-64$.

Dickerson, A. M. (2016). Millennials, affordable housing, and the future of homeownership. Journal of Affordable Housing, 24(3), 435-465.

Dutzik, T., Inglis, J., \& Baxandall, P. (2014). Millennials in motion: Changing travel habits of young Americans and the implications for public policy. Washington, DC: U.S. PIRG Education Fund. Retrieved from http://www.uspirg.org/reports/usp/millennials-motion

Gallagher, L. (2013). The end of the suburbs. New York: Portfolio/Penguin.

Greenwood, M. J. (1997). Internal migration in developed countries. In M. R. Rosenzweig \& O. Stark (Eds.), Handbook of population and family economics Vol. $1 B$ (pp. 647-720). Amsterdam: Elsevier.

Guest, A. M., \& Cluett, C. (1976). Workplace and residential location: A push-pull model. Journal of Regional Science, 16(3), 399-410.

Jennissen, R. (2007). Causality chains in the international migration systems approach. Population Research and Policy Review, 26(4), 411-436.

Jurjevich, J. R., Schrock, G., \& Kang, J. (2017). Destination Portland: Post-Great Recession migration trends in the Rose City region. Publications, Reports and Presentations 39. Portland, OR: Portland State University. Retrieved from http://pdxscholar.library.pdx.edu/prc_pub/39

Kaplan, G., \& Schulhofer-Wohl, S. (2015). Understanding the long-run decline in interstate migration. Working paper 697. Minneapolis: Federal Reserve Bank of Minneapolis.

Kelly, H. F., Billingsley, A. C., Warren, A., \& Kramer, A. (2017). Emerging trends in real estate: United States and Canada 2017. Washington, DC: Urban Land Institute.

Kennedy, P. (2001). A guide to econometrics. 4th ed. Cambridge, MA: MIT press.

King, R. (2012). Theories and typologies of migration: An overview and a primer. Willy Brandt Series of Working Papers in International Migration and Ethnic Relations. Malmö Sweden: Malmö Institute 
for Studies of Migration, Diversity and Welfare (MIM), Malmö University.

Klein, N. J., \& Smart, M. J. (2017). Millennials and car ownership: Less money, fewer cars. Transport Policy, 53, 20-29.

Korpi, M., \& Clark, W. A. (2015). Internal migration and human capital theory: To what extent is it selective? Economics Letters, 136, 31-34.

Kotkin, J., \& Cox, W. (2013). The future of the affluent American city. Cityscape: A Journal of Policy Development and Research, 15(3), 203-207.

Lee, E. S. (1966). A theory of migration. Demography, 3(1), 47-57.

Mallach, A. (2018). What does march of the millennials mean for the future of American city? In M. Moos, D. Pfeiffer, \& T. Vinodrai (Eds.), The millennial city: Trends, implications, and prospects for urban planning and policy (pp. 267-285). London: Routledge.

Molloy, R., Smith, C. L., \& Wozniak, A. (2011). Internal migration in the United States. The Journal of Economic Perspectives, 25(3), 173-196.

Moos, M., Pfeiffer, D., \& Vinodrai, T. (2018). The millennial city, shaped by contradictions. In M. Moos, D. Pfeiffer, \& T. Vinodrai (Eds.), The millennial city: Trends, implications, and prospects for urban planning and policy (pp. 3-11). London: Routledge.

Myers, D. (2016). Peak millennials: Three reinforcing cycles that amplify the rise and fall of urban concentration by millennials. Housing Policy Debate, 26(6), 928-947.

National Bureau of Economic Research. (2017). County distance database, 2010. Retrieved from http://www.nber.org/data/county-distance-database.html

Pfeiffer, D., \& Pearthree, G. (2018). The real estate industry cementing millennials' residence in urban cores and central cities? Insights from Phoenix and Houston. In M. Moos, D. Pfeiffer, and T. Vinodrai (Eds.), The millennial city: Trends, implications, and prospects for urban planning and policy (pp. 125-141). London: Routledge.

Piiparinen, R., Russell, J., \& Post, C. (2016). The fifth migration: A study of Cleveland millennials, Urban Publications, 1338. Cleveland, OH: Maxine Goodman Levin College of Urban Affairs, Cleveland State University. Retrieved from http://engagedscholarship.csuohio.edu/urban_facpub/1338

Polzin, S. E., \& Chu, X. (2014). Peak vehicle miles traveled and post-peak consequences? Transportation Research Record: Journal of the Transportation Research Board, 2453, 22-29.

Ravenstein, E. G. (1885). The laws of migration - I. Journal of the Statistical Society, 48(2), 167-227.

RSG, Inc., Coogan, M., RAND Corporation, Nelson Nygaard, \& Weinberger, R. (2017). Understanding changes in youth mobility. Washington, DC: The American Association of State Highway and Transportation Officials (AASHTO), Standing Committee on Planning. Retrieved from http://onlinepubs.trb.org/onlinepubs/nchrp/docs/NCHRP08-36(132)_FR.pdf

Schoorl, J., Heering, L., Esveldt, I., Groenewold, G., \& Van der Erf, R. (2000). Push and pull factors of international migration: A comparative report. Luxembourg: European Commission.

Sivak, M., \& Schoettle, B. (2012). Recent changes in the age composition of drivers in 15 countries. Traffic Injury Prevention, 13(2), 126-132.

Studenmund, A. H. (2001). Using econometrics: A practical guide. 4th ed. Boston: Addison Wesley Longman.

Talen, E. (2017). Empower the millennials. Housing Policy Debate, 27(2), 331-333.

TransitCenter. (2014). Who is on board? 2014 mobility attitudes survey. Retrieved from http://transitcenter.org/wp-content/uploads/2016/11/WhosOnBoard2014-ForWeb.pdf

US Census Bureau. (2017a). County-to-county migration flows: 2011-2015 ACS. Retrieved from https://www.census.gov/topics/population/migration/guidance/county-to-county-migration-flows. html 
US Census Bureau. (2017b). U.S. Gazetteer Files, 2015. Retrieved from https://www.census.gov/geo/ maps-data/data/gazetteer2015.html

US Census Bureau. (2017c). American FactFinder. Retrieved from https://factfinder.census.gov/faces/ nav/jsf/pages/index.xhtml

US Census Bureau. (2017d). Longitudinal Employer-Household Dynamics (LEHD). Retrieved from https://lehd.ces.census.gov/

US Department of Agriculture. (2017). Rural America at a glance: 2017 Edition. Washington, DC: US Department of Agriculture.

Zimmermann, K. F. (1996). European migration: Push and pull. International Regional Science Review, 19(1-2), 95-128. 